\title{
Injection Safety Practices among Medical Doctors in a Tertiary Health Institution in South Southern Nigeria
}

\author{
Obi $\mathrm{AI}^{1}$, Ofili $\mathrm{AN}^{1,2}$ \\ Department of Community Health, University of Benin Teaching Hospital, PMB 1111, Benin City, Edo State \\ and $^{2}$ Department of Community Health, University of Benin, PMB 1154, Benin City, Edo State.
}

\begin{abstract}
Unsafe injection practices are common in developing countries including Nigeria. Unsafe injection practices cause an estimated 1.3 million deaths annually globally. This study assessed injection safety practices among doctors in a Teaching Hospital in Edo Stat, utilizing a descriptive cross sectional study design. Data was analyzed using SPSS version 16.0 statistical software with statistical significance set at $p=0.05$.

Results Three hundred and nine (96.6\%) and 11(3.4\%) of respondents had good and poor knowledge of injection safety respectively. Training received on injection safety $\left(\chi^{2}=6.84 ; p=0.033\right)$ significantly influenced knowledge of injection safety. Three hundred and three (94.7\%) and 17(5.3\%) of respondents were involved in safe and unsafe injection practices. Recapping of needle and syringe was the most common unsafe injection practice $12(70.5 \%)$ with $8(47.1 \%)$ and $9(52.9 \%)$ respondents engaged in this act always and sometimes respectively.

Conclusion This study identified good knowledge and a high prevalence of safe injection safety practice among doctors but gaps exists between knowledge and practice of injection safety among doctors. There is need to strengthen frequency of training and behavior change interventions on injection safety among doctors and human resources for health to bridge this gap.

Key words: Doctors, injection safety, teaching hospital, unsafe injection practices.
\end{abstract}

Submitted date 13 June 2013

Accepted Date: 19 June 2013

\section{Introduction}

Unsafe injection practices are common in developing countries including Nigeria and worldwide up to $40 \%$ of injections are given with syringes and needles reused without sterilization and in some countries this proportion is as high as $70 \%$. Unsafe injection practices cause an estimated 1.3 million deaths each year worldwide, a loss of 26 million years of life primarily due to the transmission of blood-borne viruses such as hepatitis B and C and HIV with an annual burden amounting to approximately US\$535 million in direct medical costs. ${ }^{1}$ An effective infection control and injection safety control program should have modalities clearly spelt out to address the following ${ }^{2}$;

1. Implementation of standard precautions,

2. Education of workers and health systems managers,

3. Development of surveillance systems,

4. Immunization against hepatitis B, and

5. Implementation of appropriate post-exposure follow-up including Prophylactic medication. ${ }^{2}$

In Nigeria effort to address the poor injection safety practices in the country has led to formulation of the National Policy on Injection Safety and health care waste management ${ }^{3}$ in 2007 to address the possible factors that predispose health care workers and health care waste managers to unsafe injection practices due to the continued risk it can expose to patients, health care workers and communities. ${ }^{3}$

According to the World Health Report (2002) unsafe injection practices account for $30 \%$ of HBV infections, $31 \%$ of $\mathrm{HCV}$ infections, $28 \%$ of liver cancer, 24\% of cirrhosis cases, $5 \%$ of HIV infections and $0.9 \%$ of deaths worldwide. ${ }^{4}$

Health care workers (HCWs) are influenced by popular socio-cultural perceptions of injections, as well as having their own 'professional' beliefs that potentially contribute to the overuse of injections. In low-income countries, allopathic, traditional and informal health care providers all prescribe injectable treatments, and many subscribe to the idea that compliance is better with injections than with oral medication. ${ }^{5-6}$ Health care workers also believe that patients want injections, and if injections are not provided during consultation, patients will seek health care elsewhere, which can mean loss of status and income for some health workers. ${ }^{6}$ In addition, there may be financial incentives that encourage health workers to give injections in place of oral medication (i.e. an additional fee being charged for injection administration) especially in privately owned health care establishments. ${ }^{7-9}$ 
In Nigeria a national cross sectional study ${ }^{3}$ conducted in July/ August 2004 among 80 health facilities, about $62.5 \%$ of the health facilities were observed not to have safety boxes in use and $23.8 \%$ had no injection rooms, while $75.7 \%$ of the health care providers were observed to engage in two-handed recapping after injections (therapeutic and immunization purposes).

Also, there were poor injection practices in Nigeria especially in the area of syringe and needle over use, findings from the above study revealed an average of $4.9 \%$ injections administration per person per year and more worrisome is fact that a great majority of these injections were unnecessary and could have been replaced by oral drugs. ${ }^{3}$ In developing countries including Nigeria infection control standards are poorly implemented and most health facilities don't have functional infection control committees though reports show a high prevalence of blood borne viral infections in the region. ${ }^{10-12}$

A study in Gujarat, India ${ }^{13}$ involving selected primary health facilities and families revealed a $77 \%$ prevalence of unsafe injection practices among health care providers, these findings was similar to those from other studies in North India ${ }^{14}$ and Wulong county ${ }^{15}$ in China which had prevalence of $77.5 \%$ and $77.1 \%$ respectively.

In order to address the problems associated with unsafe injection practices the World Health Organization (WHO) in 1999 convened the Safe Injection Global Network (SIGN), which aims to promote the safe and appropriate use of injections worldwide and by implication minimize unsafe injection practices and their consequent effects. ${ }^{16}$

It is therefore important to assess injection safety practices among doctors who are key players in the health care industry and influential change agents to help address better injection safety practices and minimize unsafe injection practices and their consequences.

This study was conducted to assess the present status of injection safety practices and its associated factors among doctors in a Tertiary Teaching Hospital, in Benin City. The study findings will contribute to the body of knowledge by providing useful information to policy makers, implementers, program managers and stake holders in addressing lapses and problems identified and provide proper recommendations geared towards improving injection safety practices in the health care industry in Benin City and by extension Nigeria.

\section{Materials and Methods}

A descriptive cross sectional study was carried involving resident doctors working in a teaching hospital located in Ugbowo Community, Egor Local Government Area of Edo State between October November, 2010. The study population comprised Medical and Dental Doctors working in the hospital who had worked at least six months in the Hospital and consented to participate in the study, such a time lapse was sufficient to expose the respondents to the new work environment. A minimum sample was calculated using the Cochran formula ${ }^{16}$ using $77 \%$ prevalence of unsafe injection practices from a previous study ${ }^{13}$.

A stratified sampling technique was utilized to select respondents that participated in the study. Each of the twelve medical departments represented a stratum and based on the population size of each department a sample proportional to size of resident doctors per department as contained in the 2009 ARD directory was calculated for in relation to the calculated minimum sample size, and final selection of respondents was then made by simple random sampling technique using a table of random numbers. Pretested self administered semistructured questionnaire modified from the Safe Injection Global Network (SIGN) research tool for assessing Injection safety among Injection providers ${ }^{17}$ was then utilized for data collection following institutional approval and written informed consent from participants. Data was subsequently coded, entered and analyzed using SPSS version 16.0, association and statistical tests of association was carried with level of significance set at $p \leq 0.05$ and $95 \%$ confidence interval

\section{Results}

The mean age of respondents was $30.90 \pm 4.49$ years. Two hundred and twenty four $(70.0 \%)$ and 96(30.0\%) of the respondents were male and females respectively, and most of them were married 169(52.5\%). Christianity 303(94.7\%) was the predominant religion, followed by Islam 14(4.4\%), African Traditional Religion 2(0.6\%) while $1(0.3 \%)$ had no religious affiliation.

One hundred and seven (33.4\%) of the respondents were house officers, $102(31.9 \%), 75(23.4 \%)$ and $36(11.2 \%)$ were registrars, senior registrars and medical officers respectively. In relation to duration of professional experience $171(53.4 \%), 133(41.6 \%)$ and $16(5.0 \%)$ were in the 6-10 years, $\leq 1-5$ years and $\geq 11$ years group respectively. Also $203(63.4 \%), 100(37.2 \%)$ and $17(5.3 \%)$ of respondents interviewed had $\leq 2$ years, 3 -5 years and 6-9 years duration of work experience respectively

Majority of the respondents 314(98.1\%) interviewed were aware of infection transmission by unsafe injection practices while $6(1.9 \%)$ were not aware (See Figure 1). Seventy percent (224) of doctors were aware of the existence of an injection safety policy while (86) $26.9 \%$ were not and (10) $3.1 \%$ did not know of such policy (See Figure 2). In relation to knowledge on injection safety, 138 (43.1\%) had good knowledge, 171 
(53.4\%) had fair knowledge while $11(3.4 \%)$ had poor knowledge of injection safety. Majority of the respondents 303(94.7\%) interviewed were involved in safe injection practices while 17(5.3\%) for unsafe practices. The unsafe injection practices included reusing syringes $6.3 \%$, recapping syringes $66.3 \%$ and poor disposal of used syringes and needles $4.1 \%$ (See Figure 4). In relation to attitudes of respondents towards recapping of needle and syringe, out of the 212 respondents who recapped needle and syringe, 104 (49.1\%) engaged in the activity always while 108 (50.9\%) sometimes (See Figure 5).

Based on training received on injection safety, 193(60.3\%) of doctors studied received training on Injection safety while $127(39.7 \%$ ) had not (See Table 1). In relation to infections transmissible through unsafe injection practices; $98.7 \%, 78.3 \%, 29.9 \%$ and $3.2 \%$ of the responses respectively were for Human Immunodeficiency Virus (HIV), Hepatitis B, Hepatitis C and others (Blood Borne infection) (see Table 2). The safe injection practices respondents engaged in included $93.7 \%, 33.7 \%$ and $95.9 \%$ for not reusing, not recapping syringes and disposal of used syringes and needles into a safety boxes respectively. It shows that the most common safe injection practice was disposal of needle and syringes in safety boxes followed by not reusing syringes and needles and then recapping needles after use (see Table 3 ).

In relation to factors associated with knowledge on injection safety Table 4 showed that, 76 (47.2\%), $60(39.7 \%)$ and $2(25 \%)$ of respondents in age group 21-30 years, 31-40 years and $41-50$ years had good knowledge on injection safety but this difference was not statistically significant $(\mathrm{p}=0.526)$. Ninety three $(54.9 \%)$ and $45(50.0 \%)$ of the male and female respondents respectively had good knowledge of injection safety but this difference was not statistically significant $(\mathrm{p}=0.716)$. In relation to marital status, $66(44.0 \%), 71$ $(42.0 \%)$ and $1(100.0 \%)$ of the respondents who were single, married and co-habiting had good knowledge of injection safety but this difference was also not statistically significant $(\mathrm{p}=0.084)$.

Based on the duration of professional experience, 59 (44.4\%), $74(43.3 \%)$ and $5(31.2 \%)$ of respondents in the $\leq 5$ years, $6-10$ years and $\geq 11$ years category had good knowledge on injection safety but this difference was not statically significant $(\mathrm{p}=0.281)$. Increasing length of work experience in years resulted in decreasing level of knowledge on injection safety. Ninety four (46.3\%),40 (40.0\%) and $4(23.5 \%)$ of respondents in the $\leq 1$ year, 3-5 years and 6-9 years group had good knowledge of injection safety but this differences was found not to be statistically significant $(\mathrm{p}=0.287)$. Finally, $70(39.8 \%)$ respondents who received training on injection safety had good knowledge compared to $68(47.2 \%)$ who did not receive training and this difference was statistically significant $(\mathrm{p}=0.033)$

In relation to factors associated with injection safety practices Table 5 showed that with increasing age grouping of respondents there was increasing unsafe practices, age group $21-30$ years (unsafe practice 4.3\%) had a better injection safety practice than $31-40$ years ( unsafe practice $12.5 \%$ ) but this difference was not statistically significant $(\mathrm{p}=0.536)$. The proportion of unsafe practices was higher among males $(6.2 \%)$ than females $(3.1 \%)$ doctors, while relating to safe injection practices this was higher in the females $(96.9 \%)$ than males (93.8\%), but this differences was found not to be statistically significant ( $\mathrm{p}=0.253)$. In relation to marital status of respondents it was found out that more unmarried (singles; $95.1 \%$ and those cohabiting; $100 \%$ ) were involved in safer injection practices than married $(94.1 \%)$ while a higher proportion of married $(5.9 \%)$ than the single $(4.7 \%)$ were involved in unsafe practices, but this was not statistically significant $(\mathrm{p}=0.814)$. In terms of cadre a higher proportion of Medical officers (97.2\%), than House Officers (96.3\%), Senior Registrars (94.7\%) and Registrar (92.2\%) were engage in safe practices and vice versa for the unsafe practices, this differences was also not statistically significant $(\mathrm{p}=0.599)$. In terms of duration of professional qualification, result findings showed that the category $6-10$ years had a higher proportion of safe practice $(95.9 \%)$ and least unsafe practice $(4.1 \%)$ while the category 11 years and above had the least safe practice $(87.5 \%)$ and highest proportion of unsafe practice $(12.5 \%)$. This difference was not statistically significant $(\mathrm{p}=0.320)$. Based on length of work it was found that safe practice decreases and unsafe practices increases with increasing length of work with 2 years and below category having highest proportion of safe (95.1\%) and least proportion of unsafe (4.9\%) and 6-9 years category having the least proportion of safe (88.2\%) and highest proportion of unsafe practices $(11.8 \%)$. However, this difference was not statistically significant $(\mathrm{p}=0.476)$.

Finally, in relation to training received on injection safety, doctors who received training on injection safety a higher proportion of safer injection safety practices $168(95.5 \%)$ than unsafe injection practices 8 (4.5\%) compared with those who did not receive training on injection safety but the differences identified was not statistically significant $(\mathrm{p}=0.499)$.

In relation to knowledge on injection safety and injection safety practices Table 6 shows that safer injection practices increased with increasing knowledge on injection safety among doctors and conversely for the unsafe injection practices but these differences identified was not statistically significant ( $\mathrm{p}=0.467)$.

\section{Discussion}

A high proportion of Doctors studied had good knowledge of injection safety. This may be due to the high level of awareness on injection safety and training received on injection safety during undergraduate 
training and during pre-employment orientation course. The good knowledge of injection safety identified in this study agrees with findings from other studies conducted in Lagos University Teaching Hospital, Lagos State ${ }^{18}$ and Alexandria Teaching Hospitals, Egypt ${ }^{19}$ among Doctors, which showed that majority of respondents studied had good knowledge of injection safety.

This study also identified that majority of respondents were engaged in safe injection safety practices rather than unsafe injection practices, this level of practice was more predominant among respondents who had less than 2 years length of work experience, while the $6-9$ years length of work experience category had the highest proportion of unsafe practices. The most common unsafe injection practice identified in this study was recapping of needle and syringe. By implication doctors who have spent longer years in the establishment were more likely to be engaged in unsafe injection practices, this may explain why doctors in age group 21-30 years had a higher proportion of safe practices than those in 41-50 years age group who had the highest proportion of unsafe practices. Thus, House Officers had a higher prevalence of safe injection safety practices compared to Registrars and Senior Registrars who had higher prevalence of unsafe injection safety practices. Thus, this study further identified that younger doctors were involved in safer injection safety practices than older doctors. It is possible that junior doctors are more likely to be learning under a more strict environment and may receive punitive treatment when found wanting and as such would make less mistakes than the more senior and possibly older doctors, who may readily justify their actions.

This current study revealed a low unsafe injection practice prevalence (5.3\%) and high safe injection practice prevalence $(94.7 \%)$ among doctors generally, though inter cadre differences among doctors were observed. This finding is in contrast to study in Gujarat, India involving selected primary health facilities which revealed a high prevalence of unsafe practices of $77 \%$ among healthcare workers including doctors ${ }^{9}$ Furthermore, other studies in North India ${ }^{13}$ and Wulong County ${ }^{14}$ in China among doctors also had higher prevalence of unsafe injection practices of $77.5 \%$ and $77.1 \%$ respectively.

\subsection{Conclusion}

This study identified good knowledge of injection safety among doctors who had high prevalence of safe injection practices. Recapping of needle and syringe was the most common unsafe practice. Gap in knowledge and practice was identified in this study. There is need for regular training and re-training programs both at pre-employment and in service levels by Hospital Management on Injection safety. This will encourage the needed behavioral change measures needed to improve injection safety practices among health care workers strengthened by appropriate job aids and posters needed to call attention for safer injection safety awareness and knowledge.

\subsection{Limitation of Study}

The findings were based on self report as it was not possible to validate claims by respondents. Also incomplete questionnaire were not analyzed and this may have influenced the final result outcome.

\subsection{Acknowledgement}

I wish to specially appreciate the Management of University of Benin Teaching Hospital, Research Supervisor (Prof A.N Ofili), Research assistants and respondents for this opportunity to contribute to the body of knowledge.

\section{References}

[1]. World Health Organisation. The global burden of unsafe care in research for patient safety, WHO Publications 2008.

[2]. Updated U.S. Public Health Service Guidelines for the Management of Occupational Exposures to HBV, HCV, and HIV and Recommendations for Post exposure Prophylaxis. Vol 50, No RR11; 1

[3]. Federal Ministry of Health. National Policy on Injection safety and Health care waste Management 2007; 1-6

[4]. Miller MA and Pisani E. The cost of unsafe injections. Bulletin of the World Health Organization 1999; 77,808-81

[5]. Janszen E and Laning W. Injections: more expensive, more effective and faster. In Wolffers I and Bloem M. (eds) The Impact of Injections on Daily Medical Practice. VU University Press, Amsterdam; 1993.

[6]. Birungi H Injections and self-help: risk and trust in Ugandan health care. Social Science and Medicine, 1998; 47,1455-62

[7]. Kane A, Lloyd J, Zaffran M, Simonsen L and Kane M. Transmission of hepatitis B, hepatitis C and human immunodeficiency viruses through unsafe injections in the developing world: model-based regional estimates. Bulletin of the World Health Organization 1999; 77,801-7.

[8]. WHO. Safety of Injections. Fact Sheet No. 231/232. WHO, Geneva; 1999.

[9]. Hutin Y and Chen RT. Injection safety: a global challenge. Bulletin of the World Health Organization, 1999; 77, 787-88.

[10]. Adegboye AA, Moss GB, Soyinka F and Kreiss JK.The epidemiology of needlestick and sharp instruments accidents in a Nigerian hospital. Infection Control and Hospital Epidemiology, 1994; 15, 27-31

[11]. Consten E, Van Lanschot J, Henny P, Tinnemans J and Van der Meer J. A prospective study on the risks of exposure to HIV during surgery in Zambia. AIDS, 1995; 9,585-88.

[12]. Gumodoka B, Favot I, Berege ZA and Dolmans WM. Occupational exposure to the risk of HIV infection among health care workers in Mwanza Region, United Republic of Tanzania. Bulletin of the World Health Organization 1997; 75, 133-40.

[13]. Pandit NB and Choudhary SK. Unsafe injection safety practices in Gujarat, India. Singapore Med J $2008 ; 49$ (11): 936. 
[14]. Kotwal A, Priya R, Thakur R, et al. Injection practices in metropolis of North India, Perceptions, determents and issues of safety. Indian J Med Sci 2004; 58:334-44.

[15]. Li Q, Ou JM, Zeng G. (A cross-sectional survey on injection safety in health facilities in Wulong county, Chongqing city). Zhonghua Liu Xing Bing Xue Za Zhi 2003; 24:176-9. Chinese.

[16]. Cochran WG. Sampling techniques (3rd ed.).1977.New York: John Wiley \& Sons

[17]. USAID/NIGERIA. SIGN interviewer guide for assessing Injection Safety from injection providers in Evaluation of Injection safety and Health care Waste Management in Nigeria, 2009; 93-5

[18]. Onifade KAU, Odeyemi KA. Sharps and Sharps policies: Knowledge of Health workers at the University of Lagos Teaching Hospital, Nigeria. Nig Med Pract 2007; 52(2); 42-6

[19]. Hanafi MI, Mohammed AM, Kassem MS, Shawki M. Needle stick injuries among Healthcare workers of the University of Alexandria Hospitals, Egypt. EMHJ 2011: 17(1); 26-35

\section{Appendix}

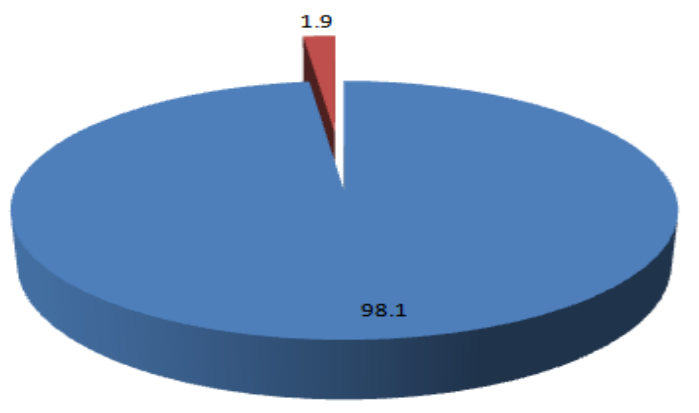

Aware

not Aware

Figure 1: Level of Awareness on Transmission of Infection by Unsafe Injection Practices

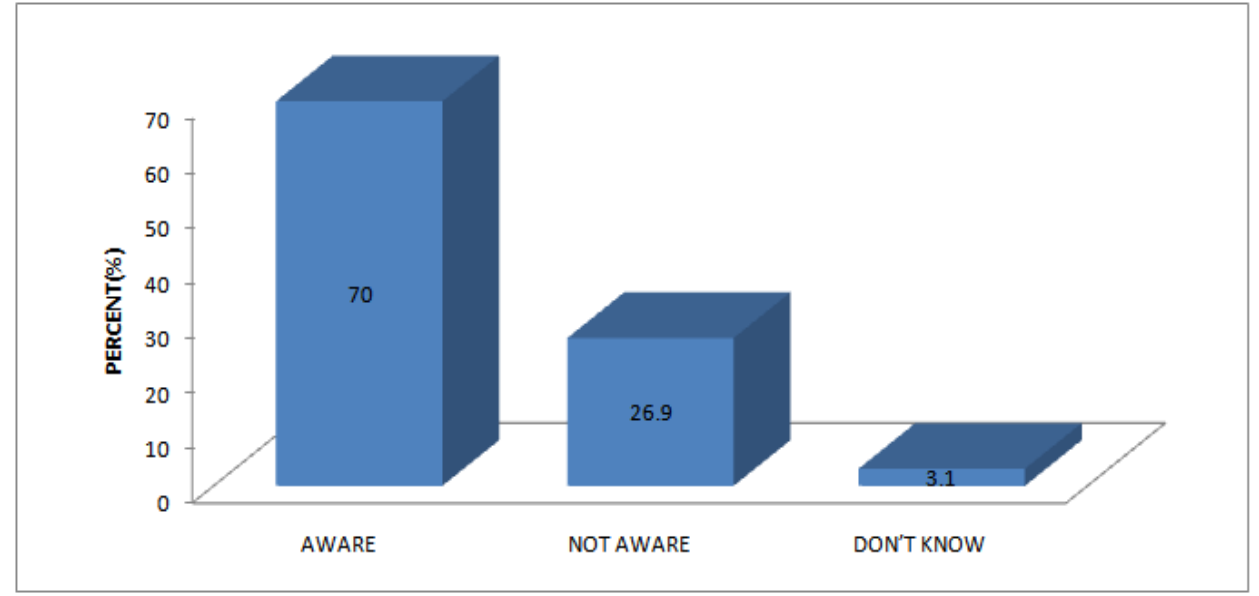

Figure 2: Level of Awareness on Existence of Injection Safety Policy

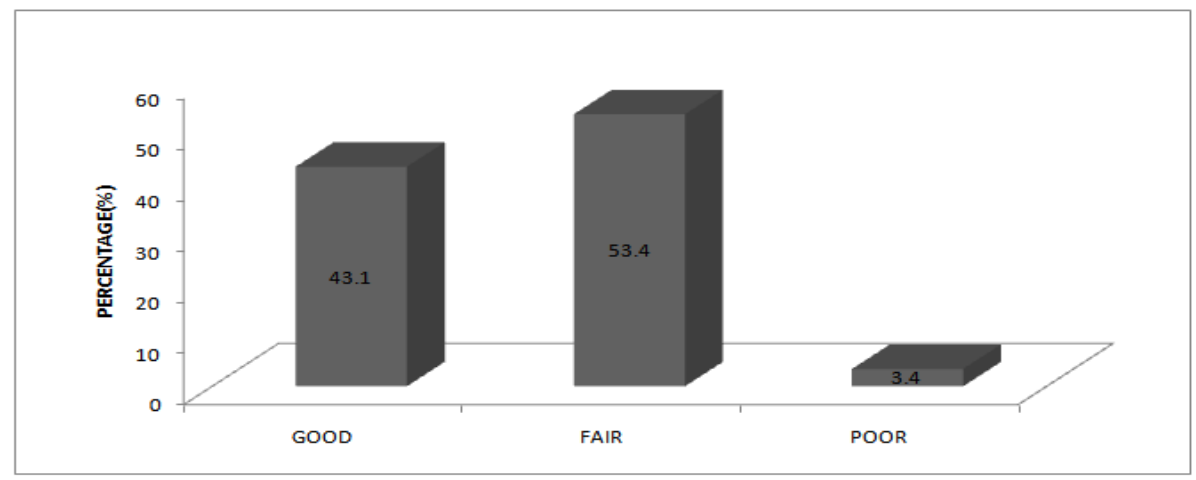


Figure 3: Level of Knowledge of Respondents on Injection Safety.

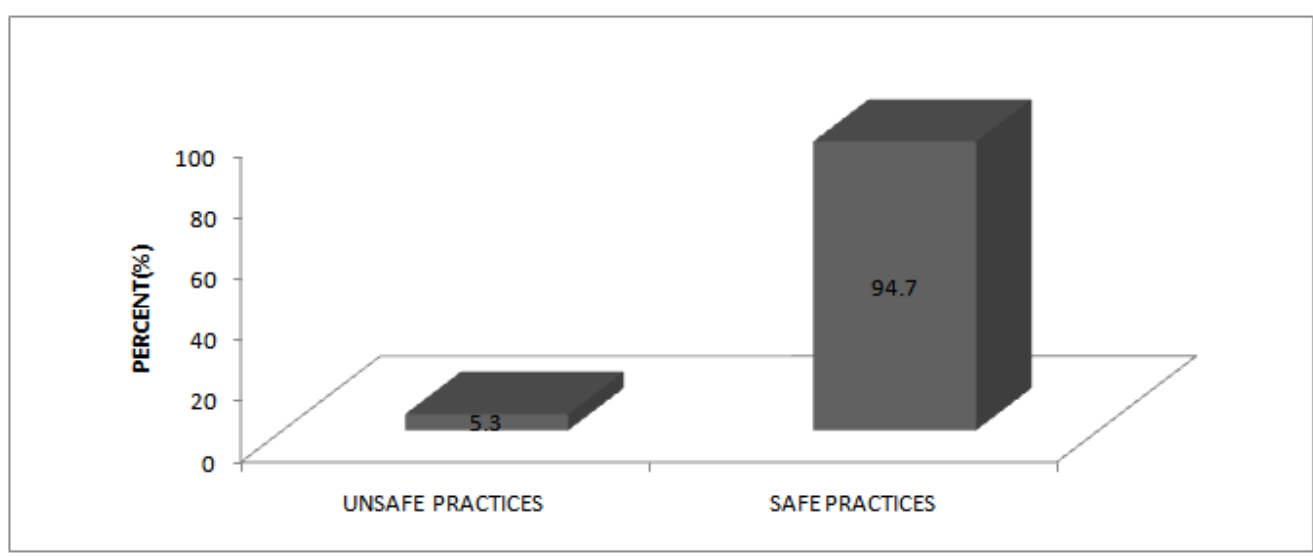

Figure 4: Injection Safety Practices among Doctors

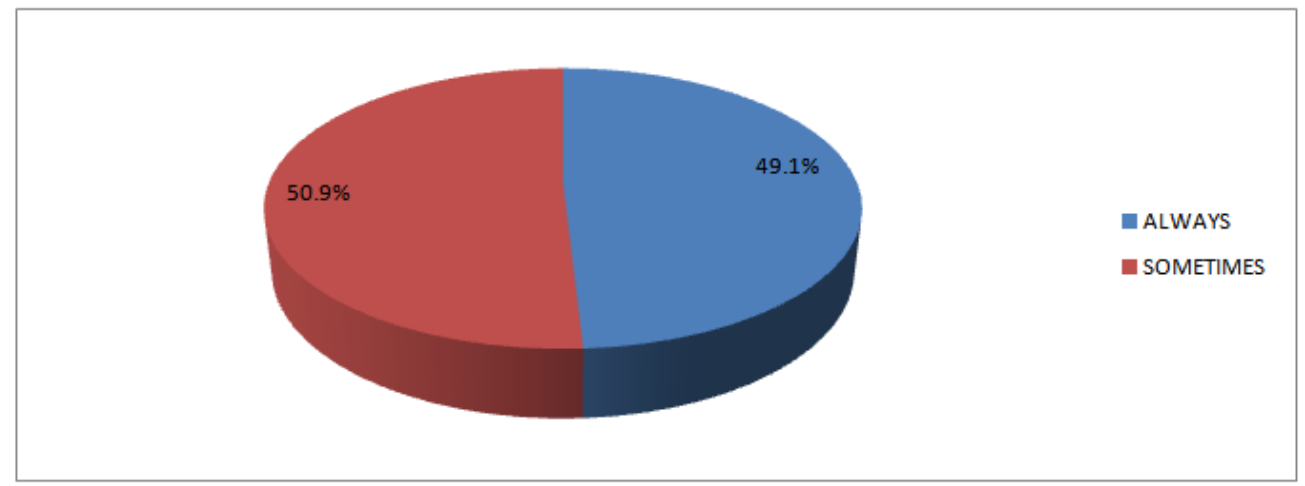

Figure 5: Attitudes of Respondents towards Recapping of Needle and Syringe

TABLE 1: TRAINING RECEIVED ON INJECTION SAFETY

\begin{tabular}{lcc}
\multicolumn{1}{c}{ RECIEVED TRAINING } & FREQUENCY & PERCENT \\
\hline YES & 193 & 60.3 \\
NO & 127 & 39.7 \\
\hline TOTAL & & 100 \\
\hline
\end{tabular}

TABLE 2: RESPONDENTS VIEW REGARDING INFECTION TRANSMISSION BY UNSAFE INJECTION SAFETY PRACTICES (N=314)

\begin{tabular}{lll} 
INFECTIONS & IREQUENCY & PERCENTA \\
\hline & & \\
HIV & 310 & 98.7 \\
HEPATITIS B VIRUS & 246 & 78.3 \\
HEPATITIS C VIRUS & 94 & 29.9 \\
OTHERS & 10 & 3.2 \\
(BLOODBORNE INFECTION) & &
\end{tabular}

*Multiple Responses 
TABLE 3: SAFE INJECTION PRACTICES BY RESPONDENTS ( $\mathbf{N}=320)$

\begin{tabular}{|c|c|c|}
\hline SAFE PRACTICES & FREQUENCY & PERCENT \\
\hline DO NOT REUSE SYRINGE & 300 & 93.7 \\
\hline DO NO RECAP NEEDLE \& SYRINGE & 108 & 33.7 \\
\hline DISPOSAL OF & & \\
\hline NEEDLE IN SAFETY BOXES & 307 & 95.9 \\
\hline
\end{tabular}

TABLE 4: FACTORS ASSOCIATED WITH KNOWLEDGE ON INJECTION SAFETY OF DOCTORS ( $\mathbf{N = 3 2 0})$

\begin{tabular}{|c|c|c|c|c|c|c|}
\hline \multirow[b]{2}{*}{ Variable } & \multicolumn{3}{|c|}{ Knowledge of Injection Safety } & & \multirow[b]{2}{*}{ Test } & \multirow[b]{2}{*}{ p-value } \\
\hline & $\begin{array}{l}\text { Good } \\
\text { Freq }(\%)\end{array}$ & $\begin{array}{l}\text { Fair } \\
\text { Freq }(\%)\end{array}$ & $\begin{array}{l}\text { Poor } \\
\text { Freq }(\%)\end{array}$ & & & \\
\hline \multicolumn{7}{|l|}{ Age } \\
\hline 21-30years & $76(47.2)$ & $80(49.7)$ & $5(3.1)$ & & Fishers & \\
\hline 31-40years & $60(39.7)$ & $85(56.3)$ & $6(4.0)$ & & Exact & $\mathrm{p}=0.526$ \\
\hline 41-50years & $2(25.0)$ & $6(75.0)$ & $0(0.0)$ & & $=3.155$ & \\
\hline \multicolumn{7}{|l|}{ Sex } \\
\hline Male & $93(41.5)$ & $123(54.9)$ & $8(3.6)$ & & $\chi^{2}=0.789$ & $\mathrm{p}=0.716$ \\
\hline Female & $45(46.9)$ & $48(50.0)$ & $3(3.1)$ & & & \\
\hline \multicolumn{7}{|l|}{ Marital Status } \\
\hline Single & $66(44.0)$ & $76(50.7)$ & $8(5.3)$ & & Fishers & \\
\hline Married & $71(42.0)$ & $95(56.2)$ & $3(1.8)$ & & Exact & $\mathrm{p}=0.196$ \\
\hline Co-habiting & $1(100)$ & $0(0.0)$ & $0(0.0)$ & & $=6.208$ & \\
\hline \multicolumn{7}{|l|}{ Designation } \\
\hline House Officer & $50(46.7)$ & $52(48.6)$ & $5(4.7)$ & & Fishers & \\
\hline Medical Officer & $18(50.0)$ & $17(47.2)$ & $1(2.8)$ & & Exact & $\mathrm{p}=0.084$ \\
\hline Registrar & $48(47.1)$ & $50(49.0)$ & $4(3.9)$ & & $=10.536$ & \\
\hline Senior Registrar & $22(29.3)$ & $52(69.3)$ & $1(1.3)$ & & & \\
\hline \multicolumn{7}{|c|}{$\begin{array}{l}\text { Duration of Professional } \\
\text { Qualification }\end{array}$} \\
\hline$\leq 1-5$ years & $59(44.4)$ & $67(50.4)$ & $7(5.3)$ & & Fishers & \\
\hline $6-10$ & $74(43.3)$ & $94(55.0)$ & $3(1.8)$ & & Exact & $\mathrm{p}=0.281$ \\
\hline$\geq 11$ & $5(31.2)$ & $10(62.5)$ & $1(6.2)$ & & $=4.754$ & \\
\hline \multicolumn{7}{|c|}{ Length of work (years) } \\
\hline$\leq 2$ years & $94(46.3)$ & $101(49.8)$ & $8(3.9)$ & & Fishers & \\
\hline $3-5$ years & $40(40.0)$ & $57(57.0)$ & $3(3.0)$ & & Exact & $\mathrm{P}=0.287$ \\
\hline $6-9$ years & $4(23.5)$ & $13(76.5)$ & $0(0.0)$ & & $=4.683$ & \\
\hline $\begin{array}{l}\text { Training on } \\
\text { safety }\end{array}$ & Injection & & & & & \\
\hline No & $68(47.2)$ & $75(52.1)$ & $1(0.7)$ & $10(5.7)$ & & \\
\hline & $70(39.8)$ & $96(54.5)$ & & & $\chi^{2}=6.84$ & $\mathrm{p}=0.033$ \\
\hline
\end{tabular}


TABLE 5: FACTORS ASSOCIATED WITH INJECTION SAFETY PRACTICES OF DOCTORS $(\mathbf{N}=\mathbf{3 2 0})$

\begin{tabular}{|c|c|c|c|c|c|}
\hline \multirow[b]{2}{*}{ Variables } & \multicolumn{3}{|c|}{ Injection Safety practices } & \multirow[b]{2}{*}{ Test } & \multirow[b]{2}{*}{ p-value } \\
\hline & $\begin{array}{l}\text { Safe } \\
\text { Freq }(\%)\end{array}$ & $\begin{array}{l}\text { Unsafe } \\
\text { Freq }(\%)\end{array}$ & $\begin{array}{l}\text { Total } \\
\text { Freq }(\%)\end{array}$ & & \\
\hline \multicolumn{6}{|l|}{ Age } \\
\hline 21-30years & $154(95.7)$ & $7(4.3)$ & $161(100.0)$ & & \\
\hline 31-40years & $142(94.0)$ & $9(6.0)$ & $151(100.0)$ & $\chi^{2}=1.245$ & $\mathrm{p}=0.536$ \\
\hline 41-50years & $7(87.5)$ & $1(12.5)$ & $8(100.0)$ & & \\
\hline \multicolumn{6}{|l|}{ Sex } \\
\hline Male & $210(93.8)$ & $14(6.2)$ & $224(100.0)$ & $\chi^{2}=1.305$ & $\mathrm{p}=0.253$ \\
\hline Female & $93(96.9)$ & $3(3.1)$ & $96(100.0)$ & & \\
\hline \multicolumn{6}{|l|}{ Marital Status } \\
\hline Single & $143(95.3)$ & $7(4.7)$ & $150(100.0)$ & Fishers & \\
\hline Married & $159(94.1)$ & $10(5.9)$ & $169(100.0)$ & Exact & $\mathrm{p}=0.814$ \\
\hline Co-habiting & $1(100.0)$ & $0(0.0)$ & $1(100.0)$ & $=1.518$ & \\
\hline \multicolumn{6}{|l|}{ Designation } \\
\hline House Officer & $103(96.3)$ & $4(3.7)$ & 107(100.0) & Fishers & \\
\hline Medical Officer & $35(97.2)$ & $1(2.8)$ & $36(100.0)$ & Exact & $\mathrm{p}=0.599$ \\
\hline Registrar & $94(92.2)$ & $8(7.8)$ & $102(100.0)$ & $=1.944$ & \\
\hline Senior Registrar & $71(94.7)$ & $4(5.3)$ & $75(100.0)$ & & \\
\hline \multicolumn{6}{|c|}{$\begin{array}{l}\text { Duration of Professional } \\
\text { Qualification }\end{array}$} \\
\hline$\leq 1-5$ years & $125(94.0)$ & $8(6.0)$ & 133(100.0) & $\chi^{2}=2.279$ & $\mathrm{p}=0.320$ \\
\hline $6-10$ & $164(95.9)$ & $7(4.1)$ & $171(100.0)$ & & \\
\hline$\geq 11$ & $14(87.5)$ & $2(12.5)$ & $16(100.0)$ & & \\
\hline \multicolumn{6}{|l|}{ Length of work (years) } \\
\hline$\leq 2$ years & 193(95.1) & $10(4.9)$ & $203(100.0)$ & & \\
\hline $3-5$ years & $95(95.0)$ & $5(5.0)$ & $100(100.0)$ & $\chi^{2}=1.487$ & $\mathrm{p}=0.476$ \\
\hline $6-9$ years & $15(88.2)$ & $2(11.8)$ & $17(100.0)$ & & \\
\hline $\begin{array}{l}\text { Training received } \\
\text { Injection safety }\end{array}$ & & & & & \\
\hline $\begin{array}{l}\text { No } \\
\text { Yes }\end{array}$ & $\begin{array}{l}135(93.8) \\
168(95.5)\end{array}$ & $\begin{array}{l}9(6.2) \\
8(4.5)\end{array}$ & $\begin{array}{l}144(100.0) \\
(100.0\end{array}$ & $\chi^{2}=0.457$ & $\mathrm{p}=0.499$ \\
\hline
\end{tabular}

TABLE 6: ASSOCIATIONS BETWEEN KNOWLEDGE OF INJECTION SAFETY AND INJECTION SAFETY PRACTICES AMONG DOCTORS.

\begin{tabular}{|c|c|c|c|c|c|}
\hline \multirow[b]{2}{*}{ VARIABLES } & \multicolumn{2}{|c|}{ KNOWLEDGE OF INJECTION } & \multirow{2}{*}{$\begin{array}{l}\text { SAFETY } \\
\text { Poor } \\
\text { Freq }(\%)\end{array}$} & \multirow[t]{2}{*}{ Test } & \multirow[t]{2}{*}{$\mathrm{P}$-value } \\
\hline & $\begin{array}{l}\text { Good } \\
\text { Freq (\%) }\end{array}$ & $\begin{array}{l}\text { Fair } \\
\text { Freq (\%) }\end{array}$ & & & \\
\hline $\begin{array}{l}\text { Injection } \\
\text { practice. }\end{array}$ & safety & & & & \\
\hline Safe & 133(96.4) & $160(93.6)$ & $10(90.9)$ & & \\
\hline Unsafe & $5(3.6)$ & $11(6.4)$ & $1(9.1)$ & $\chi^{2}=1.522$ & $\mathrm{p}=0.467$ \\
\hline
\end{tabular}

